\title{
The trk Family of Receptors Mediates Nerve Growth Factor and Neurotrophin-3 Effects in Melanocytes
}

\author{
Mina Yaar, Mark S. Eller, Peter DiBenedetto, Wende R. Reenstra, Sen Zhai, Tom McQuaid, Michael Archambault, and \\ Barbara A. Gilchrest \\ Department of Dermatology, Boston University School of Medicine, Boston, Massachusetts 02118
}

\begin{abstract}
We have recently shown that $(a)$ human melanocytes express the p75 nerve growth factor (NGF) receptor in vitro; (b) that melanocyte dendricity and migration, among other behaviors, are regulated at least in part by NGF; and (c) that cultured human epidermal keratinocytes produce NGF. We now report that melanocyte stimulation with phorbol 12-tetra decanoate 13-acetate (TPA), previously reported to induce p75 NGF receptor, also induces trk in melanocytes, and TPA effect is further potentiated by the presence of keratinocytes in culture. Moreover, trk in melanocytes becomes phosphorylated within minutes after NGF stimulation. As well, cultures of dermal fibroblasts express neurotrophin-3 (NT-3) mRNA; NT-3 mRNA levels in cultured fibroblasts are modulated by mitogenic stimulation, UV irradiation, and exposure to melanocyte-conditioned medium. Moreover, melanocytes constitutively express low levels of trk-C, and its expression is downregulated after TPA stimulation. NT-3 supplementation to cultured melanocytes maintained in Medium 199 alone prevents cell death. These combined data suggest that melanocyte behavior in human skin may be influenced by neurotrophic factors, possibly of keratinocyte and fibroblast origin, which act through high affinity receptors. (J. Clin. Invest. 1994. 94:1550-1562.) Key words: melanocytes $\bullet$ neurotrophins $\bullet$ keratinocytes $\bullet$ fibroblasts $\cdot$ receptors
\end{abstract}

\section{Introduction}

Melanocytes are neural crest-derived cells that migrate to the epidermis early in embryonic life (1) and subsequently synthesize and distribute melanin through dendritic processes to surrounding keratinocytes. Basal skin color largely results from its melanin content and distribution, and exposure to UV irradiation stimulates increased pigmentation or tanning as a protection against further photodamage (2). Little is known about the regulation of melanocyte growth and melanin synthesis, although recent identification of several melanocyte growth factors and inducers of melanogenesis have contributed to our understanding of this fastidious cell (2). We have recently

Address correspondence to Mina Yaar, M.D., Department of Dermatology J-505, Boston University School of Medicine, 80 East Concord Street, Boston, MA 02118-2394.

Received for publication 5 February 1993 and in revised form 16 June 1994.

J. Clin. Invest.

(C) The American Society for Clinical Investigation, Inc.

$0021-9738 / 94 / 10 / 1550 / 13 \$ 2.00$

Volume 94, October 1994, 1550-1562 shown that melanocytes are induced to express the p75 nerve growth factor (NGF) ${ }^{1}$ receptor in vitro by a variety of pharmacologic and physiologic stimuli including UV irradiation (3), and that NGF is chemoattractant to melanocytes, induces dendricity, and modifies their gene expression (4). Moreover, we and others have shown that keratinocytes, the predominant epidermal cells that interact with melanocytes, constitutively produce NGF, and NGF production is upregulated after UV irradiation $(5,6)$, suggesting a major paracrine role for keratinocytes in the regulation of melanocyte function.

Recently, it was found that NGF is a member of a small gene family encoding structurally and functionally related proteins called neurotrophins (NTs) which differ from each other in their effects on specific neuronal populations (7). NGF is the best studied (8), but the other neurotrophic factors, brainderived neurotrophic factor (BDNF) $(9,10)$, NT-3 (11-15), and NT-4 (16) share almost $60 \%$ amino acid homology with each other and with NGF, but have distinct range of biological activities (17) that are mediated through binding to specific receptors. Neurotrophic factors interact with at least two classes of cell surface receptors. One of these receptors is the $75-\mathrm{kD}$ GP p75 NGF receptor $(18,19)$. This receptor binds NGF, BDNF (20), NT-3 (21), and NT-4 (16) with equal affinities in the nanomolar range, but it is not alone sufficient to mediate signal transduction processes $(18,19)$. Recent studies have shown that neurotrophic factors initiate cellular signaling, as determined by induction of c-fos mRNA, changes in cellular morphology, and increased cell survival $(4,22-24)$, by binding additionally to tyrosine protein kinase receptors trk, trk-B, and trk-C. These receptor components confer binding specificity for the different neurotrophins. trk binds NGF and NT-3 $(19,22$, $23,25)$, while trk-B binds BDNF and NT-3 but not NGF (21, $23,26)$. trk-C binds only NT-3 and does not bind the highly related neurotrophic factors NGF or BDNF (27). Members of the trk gene family appear to be preferentially but not exclusively expressed in neural tissues (28-30). Transcripts of the trk gene, which encodes a $140-\mathrm{kD}$ tyrosine kinase receptor, have been identified in sensory neurons of spinal ganglia and in cranial sensory ganglia (28). The related tyrosine kinase gene trk-B encodes at least two different proteins of 145 and $95 \mathrm{kD}$ that have identical extracellular domains, but only the $145-\mathrm{kD}$ form has a cytoplasmic tyrosine kinase domain (31, 32 ). Transcripts encoding the $145-\mathrm{kD}$ BDNF and NT-3 receptor have been detected in the cerebellar cortex and the hippocampus $(30,32)$. Transcripts of trk-C, which encodes a $140-\mathrm{kD}$ tyrosine kinase receptor, have been identified in the hippocampus, the dentate gyrus, and the cerebral cortex (27).

1. Abbreviations used in this paper: BDNF, brain-derived neurotrophic factor; CNS, central nervous system; NGF, nerve growth factor; NT, neurotrophin; PKC, protein kinase C; RACE, rapid amplification of cDNA ends; TPA, 12-tetra phorbol decanoate 13-acetate. 
We now report that melanocytes express both trk and trkC mRNAs. As well, NT-3 cloned from human skin fibroblast cDNA is strongly expressed by adult and newborn fibroblasts, but not by keratinocytes, the predominant epidermal cell type, previously shown to express NGF $(4-6,32)$. NT-3 mRNA in fibroblasts is strongly modulated by growth signals, by UV irradiation, and by exposure to medium conditioned by melanocytes. Moreover, trk in melanocytes becomes phosphorylated within minutes after NGF stimulation, and melanocytes synthesize trk protein after stimulation with 12-tetra phorbol decanoate 13-acetate (TPA). TPA is a phorbol ester that binds and activates the calcium/phospholipid-dependent protein kinase $\mathrm{C}$ (PKC) $(33,34)$. The activation of PKC results in the phosphorylation of a number of intracellular proteins (35-39) that may play a role in triggering early events including cell proliferation (40), regulation of protooncogenes (41-43), and rearrangement of cytoskeleton components (44-46). PKC activation in melanocytes leads to the formation of stable dendritic processes within hours (47), suggesting that in melanocytes, PKC plays a role in cytoskeletal organization. TPA effect on trk in melanocytes is further potentiated by the presence of keratinocytes. Furthermore, melanocytes maintained in medium depleted of growth factors are rescued from cell death by NT3 supplementation, like other neural crest-derived cells treated with NT-3 $(14,15)$. Thus, melanocytes are capable of expressing high affinity receptors for NGF and NT-3; these neurotrophic factors are produced in vitro by keratinocytes and fibroblasts, respectively, cells that are adjacent to the melanocyte in vivo; the expression of NGF and NT-3 by these cells is modulated by stimuli known to alter melanocyte function in vivo. These data strongly suggest a physiologic role for these neuroregulatory proteins in controlling the differentiated function of the melanocyte in human skin.

\section{Methods}

Cell source. Normal human fibroblasts (48), keratinocytes (49), and melanocytes (50) were established from neonatal foreskin or adult skin biopsies and maintained as described. Cells were serially passed at confluence and used at second to fourth passage, at which time, for each type of cell, culture is essentially homogeneous, although the presence of a rare contaminating macrophage or other cell type cannot be completely excluded. Cells were routinely used at their confluent growth phase. For confocal microscope analysis, keratinocytes, melanocytes, or keratinocyte/melanocyte cocultures were grown on glass slides (Labtek; Nunc Inc., Naperville, $\mathbb{I L}$ ) in the appropriate medium.

Because $50 \mathrm{ng} / \mathrm{ml}$ TPA is known to induce p75 NGF receptor (3), melanocytes were treated for $1 \mathrm{~d}$ with $50 \mathrm{ng} / \mathrm{ml}$ TPA. Duplicate cultures were provided 10-100 $\mathrm{ng} / \mathrm{ml}$ TPA for $1 \mathrm{~d}$. In experiments investigating trk phosphorylation, TPA was removed from Medium $24 \mathrm{~h}$ before addition of NGF to ensure resynthesis of PKC and to eliminate stimulation of secondary messengers (i.e., raf isoforms) known to be activated by PKC $(51,52) .50 \mathrm{ng} / \mathrm{ml}$ NGF was added for $5 \mathrm{~min}$ to melanocytes maintained in Medium 199 alone.

In experiments investigating NT-3 effect on melanocyte survival, melanocytes were maintained for $3 \mathrm{~d}$ in Medium 199 lacking growth factors, and then were stimulated with $50 \mathrm{ng} / \mathrm{ml}$ or $100 \mathrm{ng} / \mathrm{ml}$ recombinant human NT-3 (PeproTech, Inc., Rocky Hill, NJ), or diluent alone. Cell yields were determined $72 \mathrm{~h}$ after stimulation.

The well-differentiated squamous cell carcinoma line SCC-12F was provided by Dr. J. Rheinwald (Brigham and Women's Hospital, Boston, MA) and was grown in DME supplemented with 5\% FCS as described (53). Fibroblasts were cultured in DME containing $10 \%$ FCS (GIBCO BRL, Gaithersburg, MD) and were used at $80 \%$ confluence. Two estab- lished melanoma cell lines were used: CRL 1619 were purchased from American Type Culture Collection (ATCC, Rockville, MD), and the MM4 human melanoma cell line was provided by Dr. U. Stierner (University of Göteborg, Göteborg, Sweden). CRL 1619 were grown in DME with 10\% FCS. MM4 were grown in 55\% DME, 29\% L15, 15\% FCS, $1 \%$ nonessential amino acids (GIBCO BRL), $2 \mathrm{mM}$ glutamine, and $10 \mu \mathrm{g} / \mathrm{ml}$ insulin. PC12 cells were purchased from ATCC and were maintained in DME containing 10\% FCS and 5\% horse serum.

Conditioned media. Medium conditioned by keratinocytes for $3 \mathrm{~d}$ was obtained from near-confluent keratinocyte cultures maintained in Medium 199 (GIBCO BRL) containing $0.09 \mathrm{mM}$ calcium supplemented with $10 \mu \mathrm{g} / \mathrm{ml}$ insulin, $10^{-9} \mathrm{M}$ triiodothyronine, $10 \mu \mathrm{g} / \mathrm{ml}$ transferrin, 2 $\mathrm{mg} / \mathrm{ml} \mathrm{BSA}, 1.4 \times 10^{-6} \mathrm{M}$ hydrocortisone, $10 \mathrm{ng} / \mathrm{ml}$ EGF, $55 \mu \mathrm{M}$ inositol, and $36 \mu \mathrm{M}$ choline chloride. Medium conditioned by melanocytes for $3 \mathrm{~d}$ was obtained from confluent melanocyte cultures maintained in Medium 199 containing $<0.03 \mathrm{mM}$ calcium supplemented with insulin, triiodothyronine, transferrin, and hydrocortisone as above, $10 \mathrm{ng} / \mathrm{ml}$ fibroblast growth factor, and 5\% chelated FBS as described (54). Medium from UV-irradiated keratinocyte and melanocyte cultures, as well as from sham-irradiated cultures, was collected (see below).

UV irradiation. The UV irradiation source was a $1 \mathrm{~kW}$ xenon arc solar simulator (XMN 1000-21; Optical Radiation Corp., Azusa, CA) filtered either with a WG 280-nm filter, a WG 305-nm filter (Kratos Analytical Instruments, Ramsey, NJ), or through the petri dish plastic cover (Becton Dickinson Labware, Lincoln Park, NJ), which provides irradiance similar to the WG 305-nm filter and relatively less shortwave UV-B than the WG 280-nm filter (55). Irradiance was adjusted to $2 \times 10^{-4} \mathrm{~W} \cdot \mathrm{cm}^{-2}$ and metered with a research radiometer (model IL1700A; International Light, Inc., Newburyport, MA) fitted with a UV-B probe (detector SSE 240, diffuser W, filter UV-B) at $285 \pm 5 \mathrm{~nm}$.

In preliminary experiments, irradiated cultures showed similar cell survival and gene modulation with all three filters. For definitive experiments, keratinocyte and fibroblast cultures were exposed to a single dose of $32 \mathrm{~mJ} \cdot \mathrm{cm}^{-2}$ (WG 280 and WG 305 filters), and melanocyte cultures were exposed to $2.4 \mathrm{~mJ} \cdot \mathrm{cm}^{-2}$ (plastic cover), doses that were chosen to fall within the physiologic range of UV expected to reach cells in irradiated human skin after a moderately erythemogenic sun exposure (56). During UV irradiation, medium was replaced with PBS to avoid formation of toxic photoproducts. Immediately after irradiation, PBS was replaced with medium.

Routinely, PBS was replaced with fresh medium. However, to prevent downregulation of NT-3 mRNA, which is observed in fibroblasts after fresh medium supplementation (see Fig. 9), cell medium was collected before UV irradiation of fibroblasts, and the cells received back their old medium after irradiation. Keratinocytes and melanocytes were provided fresh medium for periods of 8-24 h before collection. Sham-irradiated control cultures were handled identically, but placed under a dark cloth adjacent to the UV beam. Keratinocyte-conditioned medium and melanocyte-conditioned medium were collected $16 \mathrm{~h}$ after irradiation. Fibroblast cultures were harvested for Northern blot analysis $1,4,6,8$, and $24 \mathrm{~h}$ after irradiation. Cell viability after UV irradiation measured by trypan blue exclusion was $\geq 84 \%$.

RNA isolation. Total cellular RNA was isolated as described (57). Cell cultures were harvested in a 4.0-M guanidinium thiocyanate solution and passed repeatedly through a 22-gauge needle to shear the DNA and reduce the viscosity of the sample. RNA was then centrifuged through a cushion of $5.7 \mathrm{M} \mathrm{CsCl}$, resuspended in RNase-free $\mathrm{H}_{2} \mathrm{O}$, and precipitated with 0.1 vol of $3 \mathrm{M} \mathrm{NaOAc}(\mathrm{pH} 5.4$ ) and $2.5 \mathrm{vol}$ of $100 \%$ ethanol. The final RNA pellet was resuspended in RNase-free $\mathrm{H}_{2} \mathrm{O}$, and the RNA concentration and purity were calculated by absorption at 260 and $280 \mathrm{~nm}$.

Northern blot analysis. Cellular RNA was fractionated on 1\% agarose $/ 6 \%$ formaldehyde gels and transferred overnight in $20 \times$ SSC by capillarity to membranes (Hybond-N; Amersham Corp., Arlington Heights, IL) as described (57). After transfer, the RNA was covalently linked to the nylon membrane by exposure to UV light (Stratalinker 1800; Stratagene, La Jolla, CA). 
Table I. Primers Used for PCR Amplification of cDNAs

\begin{tabular}{llcc}
\hline \multicolumn{1}{c}{ Gene } & \multicolumn{1}{c}{ Primers $5^{\prime} \rightarrow 3^{\prime}$} & Location & Reference no. \\
\hline $\begin{array}{l}\text { NT-3 } \\
\text { (coding region) }\end{array}$ & TATGCAGAGCATAAGAGTCA & $508-528$ & 14 \\
NT-3 & CGGGGACACATTTTCTTG & $845-865$ & \\
$\left(3^{\prime}\right.$ RACE) & $(\text { dT })_{17}-R_{1}-R_{0}$ & & 14 \\
trk & AGTGGTTAGCCGGAATACTG & $1880-1900$ & 58,79 \\
& TTGCCTAGAGAAGCAGGAACA & $2011-2032$ & (complement) \\
trk-B & CTGCTTGGTAGGAGAGAACCT & $2006-2027$ & 32 \\
& GTTAAGAGGTCTGAGGGGTG & $2466-2486$ & (complement) \\
trk-C & GCCAGGGACACAACTGCCAC & $1584-1604$ & 27 \\
& GGCCAGGGTGGGATCCTTCA & $1752-1772$ & (complement)
\end{tabular}

The probe for trk was a $1.21-\mathrm{kb}$ human cDNA (ATCC no. 41055) (58). The probe for glyceraldehyde-3-phosphate dehydrogenase was a 1.2-kb human cDNA (ATCC no. 57090) (59). The probe for NT-3 was generated from 100-300 ng sequenced NT-3 cDNA. Radiolabeling of cDNAs was carried out using $\left[{ }^{32} \mathrm{P}\right] \mathrm{dCTP}$ (New England Nuclear, Boston, MA) and the oligonucleotide-primed DNA labeling system (Pharmacia Fine Chemicals, Piscataway, NJ) following the directions of the manufacturer. The unincorporated $\left[{ }^{32} \mathrm{P}\right] \mathrm{dCTP}$ was separated from the labeled DNA by centrifugation through a mini-spin column as recommended by the manufacturer (G50; Worthington Biochemical Corp., Freehold, $\mathrm{NJ}$ ). Blots were prehybridized for $4-6 \mathrm{~h}$ in hybridization solution at $45^{\circ} \mathrm{C}$, hybridized overnight with $5-10 \times 10^{6} \mathrm{cpm}$-labeled cDNA at $45^{\circ} \mathrm{C}$, washed as described $(60)$, and autoradiographed with XAR film (Eastman Kodak Co., Rochester, NY). Blots were developed after overnight exposure at $-70^{\circ} \mathrm{C}$. Analysis of autoradiographic band intensity was performed with a densitometer using the one-dimensional GSXL software program (Pharmacia LKB Biotechnology Inc., Piscataway, $\mathrm{NJ}$ ) with manual identification of peaks and baselines.

PCR generation of cDNAs. Human NT-3 cDNA was generated from newborn fibroblast RNA. Human trk and trk-C cDNA were generated from newborn melanocyte RNA as described (61) (Table I). Briefly, $10 \mu \mathrm{g}$ total RNA in a 20- $\mu \mathrm{l}$ vol was reverse transcribed using oligo dT12-18 (Pharmacia Fine Chemicals) as a primer. Reverse transcription was carried out for $2 \mathrm{~h}$ at $42^{\circ} \mathrm{C}$ followed by a 5 -min heating at $95^{\circ} \mathrm{C}$. After cooling on ice, $2 \mathrm{U}$ of RNase H (GIBCO BRL) was added and the sample incubated at $37^{\circ} \mathrm{C}$ for $20 \mathrm{~min}$. A $1-\mu$ l aliquot of this reverse transcription product $(0.5 \mu \mathrm{g}$ of cDNA) was then amplified with 15 pmol each of forward and reverse primers ( 20 nucleotides long) in a $100-\mu \mathrm{l}$ reaction volume using reagents from the Gene Amp kit (PerkinElmer Cetus Instruments, Norwalk, CT). For PCR amplification, primers were derived from the published rat cDNA sequences of NT-3 (14) and porcine cDNA sequences of trk-C (27). trk-C primers were constructed to correspond to nucleotide sequences not shared between human trk and porcine trk-C. trk primers were derived from published human trk sequences located at the $3^{\prime}$ end of the trk oncogene $(58,58 a)$.

To examine trk and trk-C expression, initially 40 cycles of amplification were performed on CDNA, as well as on RNA, from each sample to assure no contamination of RNA samples with genomic DNA. Subsequently, all PCR reactions were terminated at the exponential phase of amplification ( 20 cycles), which was found to be sufficient for optimal detection of trk and trk-C expression and allowed quantitative analysis of mRNA transcripts (see Fig. $1 E$ ). Denaturation was performed at $95^{\circ} \mathrm{C}$ for $1 \mathrm{~min}$, primer annealing at $45^{\circ} \mathrm{C}$ for $1 \mathrm{~min}$, and DNA polymerization at $72^{\circ} \mathrm{C}$ for $1 \mathrm{~min}$ in a microcycler (Eppendorf North America, Inc., Madison, WI). DNA products were analyzed on 3\% agarose gel in $1 \times$ TAE and stained with ethidium bromide. For asymmetric PCR amplification, to generate single-stranded DNA, one primer (either the $5^{\prime}$ or $3^{\prime}$ primer) was used at a concentration of $50 \mathrm{pM}$ and the other primer was used at a concentration of $1 \mathrm{pM}$.

Generation of the NT-3 cDNA $3^{\prime}$ end was carried out using the RACE (rapid amplification of cDNA ends) procedure as described (62).
Reverse transcription was carried out using a "hybrid" primer consisting of oligo-dT linked to a unique "double-adapter" sequence $\left[(d T)_{17}-R_{1}-R_{0}\right]$ provided by the manufacturer (Perkin-Elmer Cetus Instruments). PCR amplification was carried out as described above using the hybrid primer $\left[(d T)_{17}-R_{1}-R_{0}\right]$ and an NT-3-specific primer based on our initial human NT-3 cDNA sequence.

Cloning and sequencing. Single-stranded DNA was sequenced using the chain termination method of Sanger et al. (63). Double-stranded, PCR-generated cDNAs were first treated with DNA polymerase I large fragment (Klenow fragment) to fill in any incomplete strands. The entire PCR sample was adjusted to $10 \mathrm{mM} \mathrm{MgCl}_{2}$, then $6 \mathrm{U}$ Klenow enzyme (Pharmacia Fine Chemicals) was added to the reaction and incubated at room temperature for $20 \mathrm{~min}$. The DNA fragment to be cloned was then recovered from a $1.5 \%$ agarose gel using the Geneclean kit as suggested by the manufacturer (BIO 101, Inc., La Jolla, CA). The 5' ends of the DNA were phosphorylated by incubating the isolated DNA fragments in $20 \mu \mathrm{l}$ of $1 \times$ kinase buffer (Pharmacia Fine Chemicals), $1 \mathrm{mM}$ ATP, and $20 \mathrm{U}$ T4 polynucleotide kinase (Pharmacia Fine Chemicals) for $30 \mathrm{~min}$ at $37^{\circ} \mathrm{C}$. The sample was again run on an agarose gel and the DNA isolated and cleaned as before.

The vector pBluescript SK + (Stratagene) was prepared by digestion with EcoRV (GIBCO BRL). Then, the cut vector was isolated from an agarose gel as described above. To prevent religation of cut vector, the restricted DNA was treated with $100 \mathrm{U}$ bacterial alkaline phosphatase (GIBCO BRL) in a final volume of $100 \mu$, then recovered by ethanol precipitation. Insert and vector DNA (1:1) were ligated with $5 \mathrm{U}$ T4 DNA ligase (Pharmacia Fine Chemicals) in $10 \mu \mathrm{l} 1 \times$ reaction buffer (supplied by Pharmacia Fine Chemicals) and $1 \mathrm{mM} \mathrm{ATP}$, at $14^{\circ} \mathrm{C}$ overnight.

The ligation reaction was used to transform competent XLI-Blue cells (Stratagene) as described (57). Transformed cells were selected on ampicillin plates containing isopropylthiogalactoside and Bluo-Gal (GIBCO BRL) to help identify colonies containing inserts. All ampicillin-resistant colonies were transferred to membranes (Duralose-UV; Stratagene), denatured, and fixed according to the manufacturer. Bacterial lifts were screened with ${ }^{32} \mathrm{P}$-labeled NT-3 cDNA previously sequenced after asymmetric PCR amplification as described (57). Positive colonies were grown overnight in 3-ml mini-preps, and the plasmid DNA was isolated by a lysozyme boiling method described by Stratagene for pBluescript vectors. Double-stranded DNA was denatured in $0.2 \mathrm{M} \mathrm{NaOH}, 0.2 \mathrm{mM}$ EDTA for $5 \mathrm{~min}$ at room temperature, neutralized with $0.4 \mathrm{M}$ ammonium acetate, $\mathrm{pH} 5.4$, and precipitated with $2 \mathrm{vol}$ of $100 \%$ ethanol. The denatured DNA was sequenced using the chain termination method of Sanger et al. (63).

Southern blot analysis. Aliquots from PCR-generated trk and trk-C cDNA samples, usually $10-20 \mu \mathrm{l}$, were separated on $3 \%$ and $1.5 \%$ agarose gels. After electrophoresis, the $3 \%$ gels were stained with ethidium bromide and photographed, while the DNA on the $1.5 \%$ gel was nicked by soaking the gel in $0.2 \mathrm{~N} \mathrm{HCl}$ for $10 \mathrm{~min}$, denatured by soaking in $0.5 \mathrm{M} \mathrm{NaOH}, 1.5 \mathrm{M} \mathrm{NaCl}$ for $50 \mathrm{~min}$, and neutralized in $1 \mathrm{M}$ Tris $\mathrm{HCl} \mathrm{pH} \mathrm{8.0,1.5} \mathrm{M} \mathrm{NaCl} \mathrm{for} 50 \mathrm{~min}$. DNA was transferred to Hybond$\mathrm{N}$ membranes overnight by capillarity in $10 \times \mathrm{SSC}$ and, after linking of the DNA to the nylon membrane by exposure to UV light, the membrane was stained with ethidium bromide and the molecular weight standards were marked. $10 \mathrm{ng}$ each of 1.21-kb trk cDNA (ATCC no. 41055) (53), a 0.995-kb porcine trk-C cDNA (ATCC no. 41063) (27), and a 3.171-kb mouse trk-B cDNA (ATCC no. 63055) (29) were labeled using $\left[{ }^{32} \mathrm{P}\right] \mathrm{dCTP}$ (New England Nuclear) and the oligonucleotideprimed DNA labeling system (Pharmacia Fine Chemicals) following the directions of the manufacturer. Triplicate blots containing PCRgenerated trk and trk-C cDNA were hybridized at the same time to equal amounts of comparable specific activity radiolabeled trk, trk-C, and trk-B cDNAs. Blots were developed after 2-5-h exposure. Analysis of autoradiographic band intensity was performed with a densitometer using the one-dimensional GSXL software program with manual identification of peaks and baselines.

Western blot analysis. Melanocyte proteins were collected in sample buffer (0.5 M Tris-HCl [pH 6.8], 20\% glycerol [vol/vol], 10\% SDS 
[wt/vol], and $0.1 \mathrm{M}$ dithiothreitol) and processed as above. $4.5 \mu \mathrm{g}$ of protein was separated on 7.5\% SDS-PAGE and blotted onto nitrocellulose paper (overnight, $40 \mathrm{~V}$ ). Blots were incubated with a mouse monoclonal antiphosphotyrosine $\mathrm{IgG}_{2} \mathbf{0 . 7} \mu \mathrm{g} / \mathrm{ml}$ (primary antibody) (Oncogene Science, Inc., Manhasset, NY) followed by horseradish peroxidase-conjugated goat anti-mouse IgG (Bio Rad Laboratories, Herculus, CA). Duplicate cultures supplemented for $48 \mathrm{~h}$ with TPA were processed identically and incubated with $0.1 \mu \mathrm{g} / \mathrm{ml}$ affinity-purified rabbit anti-trk polyclonal antibody raised against the peptide ALANAPPVYLDVLG, present in the $\mathrm{COOH}$-terminal domain of human trk (primary antibody) (Oncogene Science, Inc.) (27). Followed by horseradish peroxidase-conjugated goat anti-rabbit IgG (Bio Rad Laboratories) ALANAPPVYLDVLG peptide shares $64 \%$ and $71 \%$ amino acid homology with porcine trk-C and mouse trk-B, respectively. Bound antibodies were detected using enhanced chemiluminescence kit (Amersham Corp.).

Confocal image analysis of anti-trk binding. Labtek slides with TPAstimulated melanocytes, as well as TPA-stimulated keratinocyte/melanocyte cocultures, were fixed with Histochoice (Amresco, Solon, $\mathrm{OH}$ ) and incubated with $0.2 \mu \mathrm{g} / \mathrm{ml}$ of the affinity-purified rabbit anti-trk polyclonal antibody (Oncogene Science, Inc.). The second antibody was FITC-conjugated goat anti-rabbit IgG. Representative cells were photographed and their level of fluorescence was analyzed as described $(64,65)$.

\section{Results}

Expression of trk mRNA in melanocytes. Total RNA was isolated from confluent melanocyte cultures treated for $1 \mathrm{~d}$ with TPA, or from melanocyte cultures maintained in melanocyte medium alone. Using sequence-specific human trk primers and the PCR technique, only samples of TPA-stimulated reverse transcribed melanocyte RNA analyzed by ethidium bromidestained agarose gel showed a single band of the predicted 162 bp (Fig. $1 A$ ). The specificity of the generated band was examined by Southern blot analysis. PCR products of control and TPA-stimulated melanocytes were hybridized to ${ }^{32} \mathrm{P}$-labeled human trk cDNA (58), TPA-stimulated melanocyte cDNA showed strong hybridization to the 162-bp band, verifying the specificity of the band, and the control monocyte cDNA showed a fainter band (Fig. $1 B$ ).

To rule out the possibility that the amplified band represents trk-C or trk-B, triplicate blots were hybridized with equal amounts of radiolabeled trk, trk-C, and trk-B cDNAs with comparable specific activities. Only trk cDNA hybridized to the generated band confirming its specificity (Fig. $1 C$ ). Samples of melanocyte cDNA that were amplified with sequence-specific human GAPDH primers and processed identically to the first samples confirm comparable amplification of samples (Fig. 1, $A$ and $C$ ). Samples of melanocyte RNA that were not reverse transcribed but otherwise processed identically to the first samples served as a negative control (Fig. 1, $A$ and $C$ ). Furthermore, total cellular RNA from control or TPA-stimulated melanocytes and PC12 cells was analyzed by Northern blotting for trk expression. trk $3.2-\mathrm{kb}$ transcripts were observed only in TPAstimulated melanocytes (Fig. $1 \mathrm{D}$ ).

To see if TPA induction of trk mRNA in melanocytes is dose-dependent, melanocytes were incubated for $1 \mathrm{~d}$ with 10 , $20,40,50$, or $100 \mathrm{ng} / \mathrm{ml}$ TPA or diluent alone. Total cellular RNA was processed by PCR as above and hybridized in the Southern blotting technique to ${ }^{32} \mathrm{P}$-labeled human trk cDNA. Compared to unstimulated control, there was an approximately fivefold induction of trk mRNA in cultures stimulated with $20-$ $50 \mathrm{ng} / \mathrm{ml}$ TPA (Fig. $1 E$ ). trk phosphorylation in melanocytes. To determine if NGF induces trk phosphorylation in melanocytes, cells were first stimulated with TPA and were then maintained in Medium 199 lacking growth factors. After $24 \mathrm{~h}$, cultures were stimulated for $5 \mathrm{~min}$ with $50 \mathrm{ng} / \mathrm{ml} \mathrm{NGF}$ or diluent alone. Total melanocyte proteins were processed for Western blotting using anti-phosphotyrosine antibodies. A broad band of 130-140 kD apparent mol mass was seen only in NGF-stimulated cultures (Fig. $2 A$ ). An additional band migrating below the $116.5-\mathrm{kD}$ standard was seen only in NGF-stimulated cultures.

Duplicate TPA-stimulated cultures were processed for Western blotting using affinity-purified anti-trk antibody. A prominent band of $\sim 130 \mathrm{kD}$ apparent molecular mass was seen (Fig. 2 B). A weaker band migrating at $\sim 110 \mathrm{kD}$ was also detected, consistent with a glycosylated trk precursor. However, because the anti-trk antibody used in our study was raised against a peptide that shares $64 \%$ and $71 \%$ amino acid homology with porcine trk-C and mouse trk-B, respectively (27), the possibility of the antibody additionally recognizing other forms of trk cannot be excluded.

Expression of trk protein in melanocytes. To further determine if melanocytes express trk protein, TPA-stimulated melanocytes, as well as TPA-stimulated keratinocyte/melanocyte cocultures, were grown on Labtek slides (Fig. 3). Using indirect immunofluorescence and purified rabbit anti-trk antibodies, TPA-stimulated melanocytes either in pure culture (Fig. $3 A$ ) or in keratinocyte/melanocyte coculture (Fig. $3 C$ ) showed strong surface fluorescence as compared to keratinocytes analyzed at the same laser voltage and intensity (Fig. $3 E$ ). Again, the possibility of the antibody additionally recognizing other forms of trk cannot be excluded.

Expression of trk-C mRNA in melanocytes. To determine if melanocytes express trk-C mRNA, samples of control or TPAstimulated reverse-transcribed melanocyte RNA were amplified in the PCR technique using primers complementary to porcine trk-C cDNA selected to represent sequences not shared between human trk and porcine trk-C. Samples of melanocyte RNA that were not reverse transcribed but were otherwise processed identically to the first samples served as a negative control. ${ }^{32} \mathrm{P}$ labeled porcine trk-C probe strongly hybridized to the predicted 228-bp band in control melanocyte cDNA and displayed only a faint band in TPA-stimulated melanocyte cDNA, confirming that melanocytes express trk-C mRNA primarily under baseline conditions (Fig. $4 A$ ). Duplicate samples of melanocyte cDNA that were amplified with sequence-specific human GAPDH primers and processed identically to the first samples confirm comparable amplification of samples (Fig. $4 A$ ). To rule out the possibility that the amplified band represents trk or trk-B, triplicate blots were hybridized with equal amounts of comparable specific activity-radiolabeled trk, trk-C, and trk-B cDNAs. Only trk-C cDNA hybridized to the generated band, confirming its specificity (Fig. $4 \mathrm{~B}$ ).

Effect of NT-3 on melanocyte survival. To determine NT-3 effect on melanocytes, confluent cultures were maintained for $3 \mathrm{~d}$ in Medium 199 lacking growth factors. Then, cells were stimulated with 50 or $100 \mathrm{ng} / \mathrm{ml}$ recombinant human NT-3 or diluent alone. In cultures supplemented for $72 \mathrm{~h}$ with NT-3, melanocytes appeared healthy and were spread on the dish surface (Fig. 5 B). In contrast, melanocytes maintained in Medium 199 alone were dying and detaching from the dish surface (Fig. $5 \mathrm{C}$ ). Cell yields were $>10$-fold higher in cultures supple- 


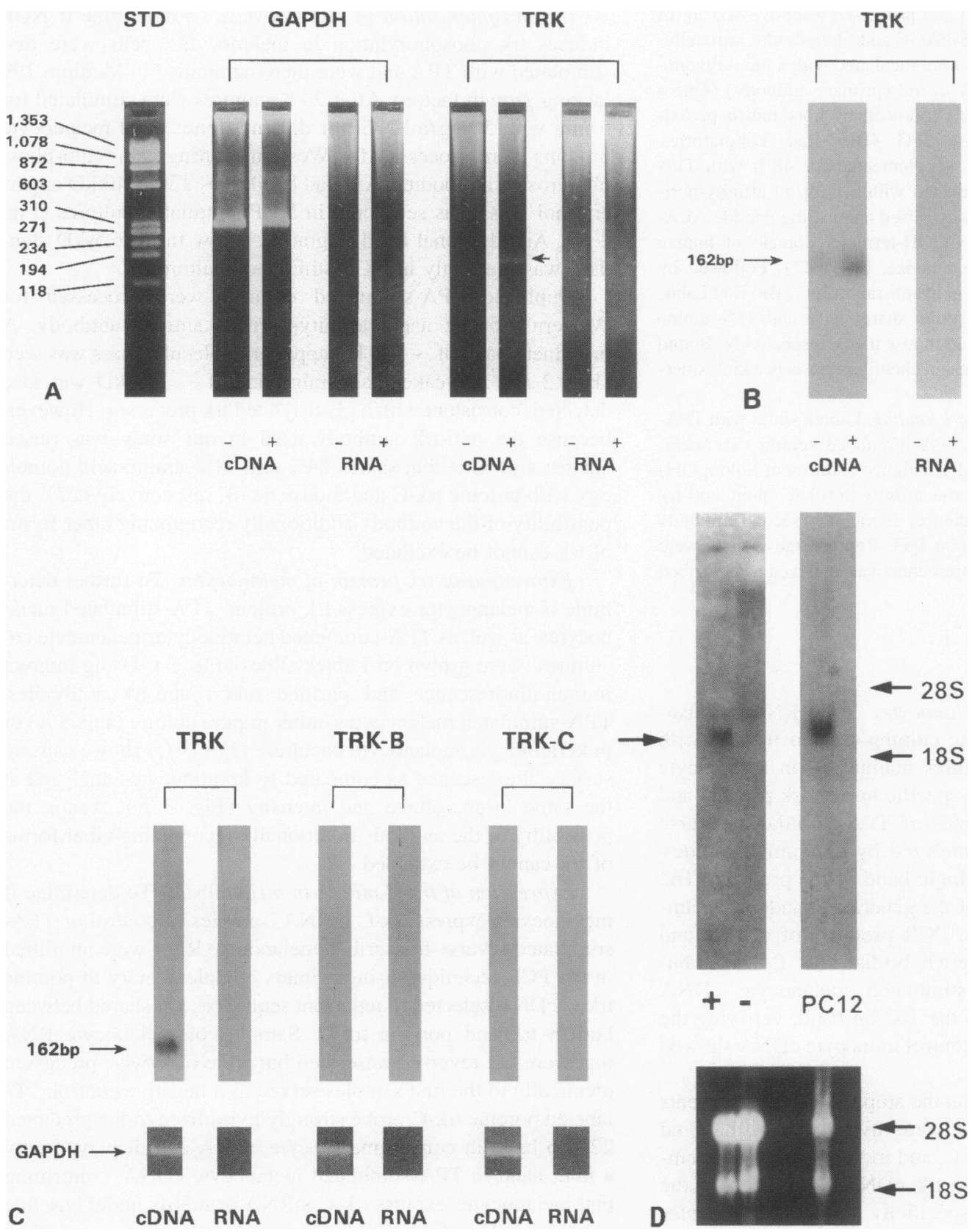

Figure 1. Trk gene expression by human melanocytes. $(A)$ Ethidium bromide-stained PCR products of reverse-transcribed control ( - ) and TPA-stimulated $(+)$ melanocyte mRNA amplified using sequence-specific human trk primers, separated on $3 \%$ agarose gel. After $40 \mathrm{cy}-$ cles, no band is seen in control melanocyte cDNA, but a band of the predicted 162-bp size is seen in cDNA of melanocytes treated for $1 \mathrm{~d}$ with $50 \mathrm{ng} /$ ml TPA (arrow). Bands of comparable intensity are present in duplicate samples amplified with human GAPDH sequence-specific primers, suggesting comparable amplification of both samples. No bands are seen in non-reversetranscribed melanocyte mRNA, excluding the possibility that trk and

GAPDH bands were generated from contaminating genomic DNA molecules. Standard (STD) is $\phi \chi 174$ replicative form DNA digested with HoeIII. $(B)$ Southern blot analysis of PCR products of reversetranscribed control (-) and TPA-stimulated (+) melanocyte mRNA, and non-reverse-transcribed melanocyte mRNA of the same samples shown in $(A)$ separated on $1.5 \%$ agarose gel. The blot was hybridized to ${ }^{32} \mathrm{P}$-labeled human trk cDNA (ATCC no. 41055). A strong band is seen in the TPA-stimulated melanocyte cDNA and a fainter band

is seen in control melanocyte cDNA. No band is seen in non-reverse-transcribed melanocyte mRNA, excluding the possibility that the trk band was generated from contaminating genomic DNA. $(C)$ Southern blot analysis of PCR products ( 20 cycles) of reverse-transcribed, TPA-stimulated melanocyte mRNA, and non-reverse-transcribed melanocyte mRNA of the same samples separated on $1.5 \%$ agarose gel. The blots were hybridized at the same time to equal amounts of comparable specific activity radiolabeled trk (ATCC no. 41055), trk-C (ATCC no. 41063), and trk-B (ATCC no. 63055) cDNAs. As a positive control for trk B, rat brain cDNA was amplified with trk-B sequence-specific primers (see Table I) and was hybridized with trk-B cDNA (ATCC no. 63055) (data not shown). A strong band is seen only in melanocyte cDNA hybridized with trk cDNAs. No band is seen in non-reverse-transcribed melanocyte mRNA. Ethidium bromide-stained PCR products of reverse-transcribed melanocyte mRNA amplified with GAPDH primers separated on 3\% agarose gel display bands of comparable intensity in all samples. $(D)$ Northern blot analysis of total melanocyte and PC12 RNA. $50 \mu \mathrm{g}$ of control $(-)$ or TPA-stimulated (+) melanocyte mRNA and $30 \mu \mathrm{g}$ of PC12 RNA, used as a positive control, were processed for Northern blotting and hybridized with ${ }^{32}$ P-labeled trk cDNA (ATCC no. 41055). Only PC12 cells and TPA-stimulated melanocytes express the 3.2-kb trk transcript (arrow). Ethidium bromide staining of the gel demonstrates comparable loading of melanocyte samples. 1-wk exposure is shown for melanocytes and overnight exposure for PC12 cells. $(E)$ Southern blot analysis of PCR products (20 cycles) of TPA-stimulated reverse-transcribed melanocyte mRNA. Cells were stimulated for $1 \mathrm{~d}$ with 10-100 $\mathrm{ng} / \mathrm{ml}$ TPA or diluent alone (CTL). Blot was hybridized to ${ }^{32} \mathrm{P}$-labeled human trk cDNA (ATCC no. 41055 ). Hardly any trk transcripts are seen in control melanocyte cDNA. A dose-dependent increase in trk expression is seen with increasing TPA doses with maximal expression in melanocytes stimulated with $40 \mathrm{ng} / \mathrm{ml}$ TPA. 
trk
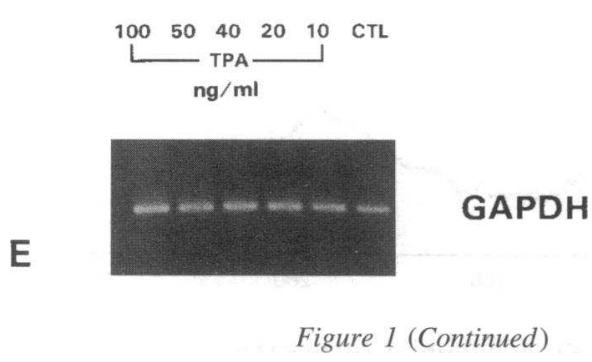

mented with NT-3 as compared to cultures supplemented with diluent alone (Fig. $5 \mathrm{~A}$ ).

Expression of human NT-3 in skin-derived cells. Because previous studies have demonstrated NT-3 mRNA in adult rat skin (14), oligonucleotide primers were designed based on the rat sequence and used in PCR amplification of human CDNA obtained from reverse-transcribed RNA of three skin-derived cells: $(a)$ keratinocytes, known to express mRNA for NGF; $(b)$ melanocytes; and $(c)$ fibroblasts. The expected 357-bp band was seen only in fibroblast cDNA and not in keratinocyte or melanocyte cDNA (Fig. 6). Sequence analysis of this fragment revealed $100 \%$ homology with the published human NT-3 DNA (66). Based on these results, we concluded that the PCR-generated cDNA represents fibroblast-derived human NT-3 and it was used in subsequent experiments to examine NT-3 mRNA transcription levels.

NT-3 expression was examined by Northern blot analysis in total cellular RNA extracted from human newborn fibroblasts and keratinocytes, a squamous carcinoma cell line SCC12F, and two human melanoma cell lines, MM4 and 1619. NT-3 1.4-kb transcripts were observed only in fibroblasts (Fig. 7). Because neurotrophic factors are known to be important particularly during fetal development, we wanted to see if NT-3 expression is restricted to newborn cells. Total RNA of fibroblasts from donors aged 23-81 yr was analyzed by Northern blotting for NT-3 expression. NT-3 transcripts were strongly expressed in donors of all ages (Fig. 8), suggesting a role for NT-3 in the adult organism.

Because neurotrophic factors are believed to be produced by cells in proximity to the target neuron (67-69) and, at least in the brain, neuronal activity modulates their expression in a way that suggests a paracrine interaction (70), we examined the effect of melanocyte-derived signals on NT-3 expression in fibroblasts. Also, because it was reported that injury to the brain, specifically ischemia or hypoglycemia, modulates neurotrophic mRNA expression (70), we examined the effect of UV irradiation, the best known injurious environmental agent for the skin, and mitogen deprivation on NT-3 expression in fibroblast cultures. Total RNA was extracted from near-confluent fibroblast cultures at different times up to $\mathbf{5} \mathrm{d}$ after provision of fresh medium, and from UV-irradiated fibroblasts. Fibroblasts were also maintained in medium conditioned by keratinocytes or melanocytes, or in medium conditioned by UV-irradiated keratinocytes or melanocytes.

NT-3 1.4-kb transcript level was strongly downregulated by provision of fresh medium within $4 \mathrm{~h}$, then gradually increased 25-fold through $5 \mathrm{~d}$ (Fig. $9 \mathrm{~A}$ ). Melanocyte-conditioned medium upregulated NT-3 mRNA level within $6 \mathrm{~h}$ after stimulation (Fig. $9 B$ ). No NT-3 mRNA was observed in fibroblasts provided with fresh nonconditioned medium, probably because provision of fresh medium downregulated NT-3 mRNA level in fibroblasts. Medium from UV-irradiated melanocytes did not differ in this regard from medium conditioned by sham-irradiated cells. Different keratinocyte-conditioned media did not affect NT-3 expression by fibroblasts. UV irradiation of fibroblasts downregulated their NT-3 mRNA level > 11-fold (Fig. $9 C$ ) with more injurious shortwave UV-B-enriched light more effective than shortwave UV-B-depleted light.

Molecular cloning and sequence analysis of the $3^{\prime}$ untranslated region of $N T-3$. The $3^{\prime}$ RACE procedure produced two cDNAs of $\sim 500$ and 630 bp in length that strongly hybridized to NT-3 cDNA (Fig. $10 \mathrm{~A}$ ). These cDNAs were cloned and the previously unpublished sequences are in Fig. $10 \mathrm{~B}$. There is $\sim 86 \%$ nucleotide sequence homology between rat and human NT-3 in the newly sequenced region of the $3^{\prime}$ untranslated area, suggesting that this area may be important potentially for mRNA stability or translation. The last 36 bases in this region were never published in the rat and, therefore, the homology could not be determined. Also, an additional putative polyadenylation signal is present in human NT-3, suggesting that the

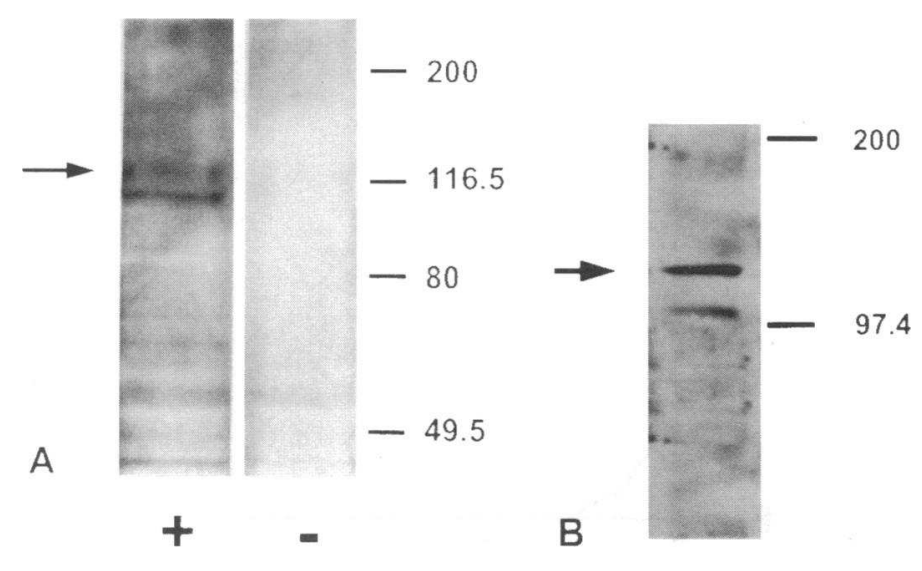

Figure 2. Western blot analysis of trk and NGF-induced trk phosphorylation. $(A)$ TPA-treated melanocytes maintained in Medium 199 alone were stimulated for $5 \mathrm{~min}$ with $50 \mathrm{ng} / \mathrm{ml} \mathrm{NGF} \mathrm{(+)} \mathrm{or}$ with diluent alone (-). $4.5 \mu \mathrm{g}$ of total melanocyte proteins was processed for Western blotting and hybridized with anti-phosphotyrosine antibody. The expected $130-140-\mathrm{kD}$ phosphorylated trk is seen only in NGF-treated cultures (arrow). An additional band comigrating close to the $116.5-\mathrm{kD}$ standard is seen only in NGFstimulated cultures. $(B) 4.5 \mu \mathrm{g}$ of total melanocyte proteins from duplicate cultures maintained for $48 \mathrm{~h}$ in TPA was processed identically and hybridized with anti-trk antibody. The expected 130-140 $\mathrm{kD}$ trk band is seen. The band migrating at $110 \mathrm{kD}$ may represent a glycosylated precursor of trk. 

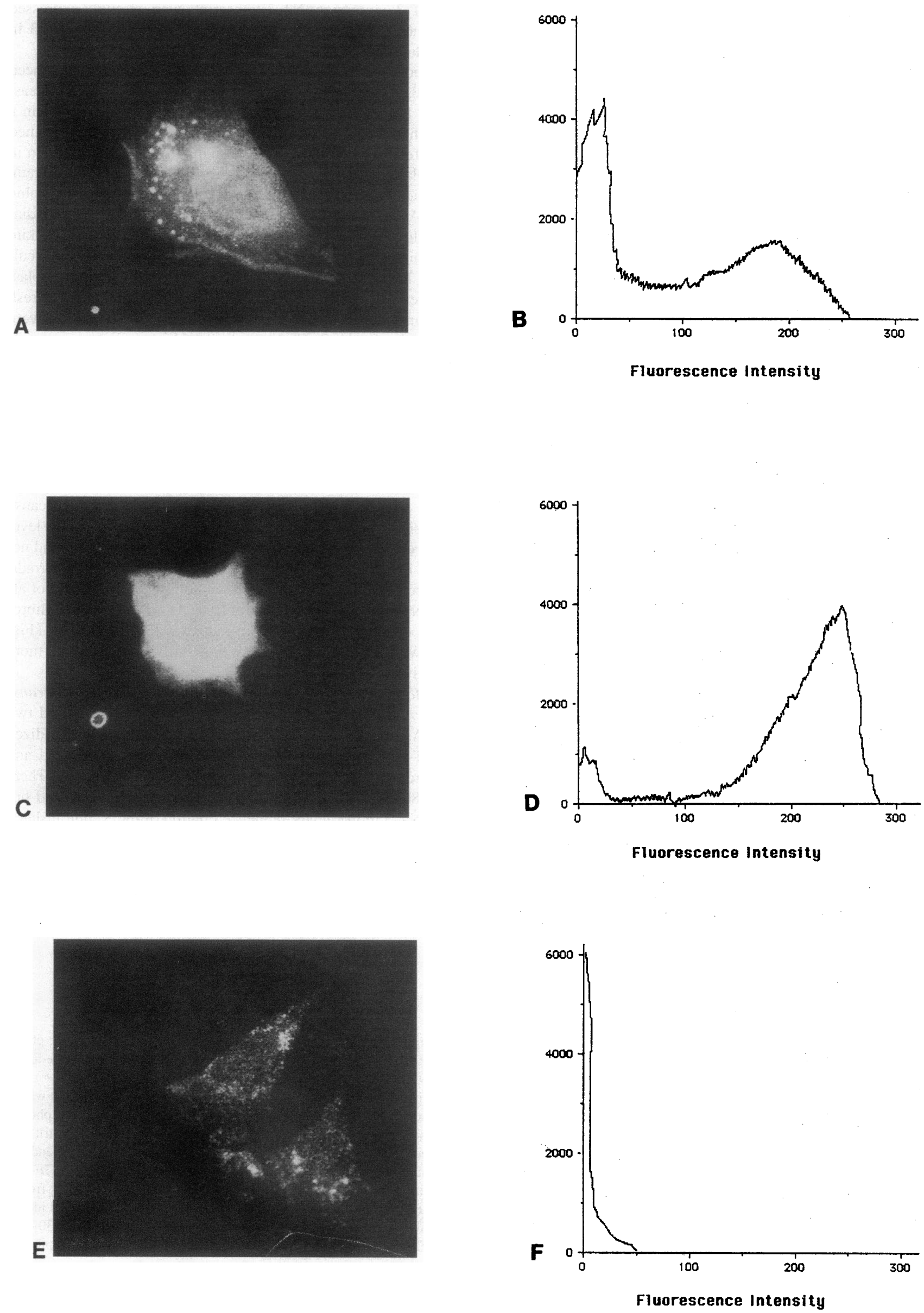


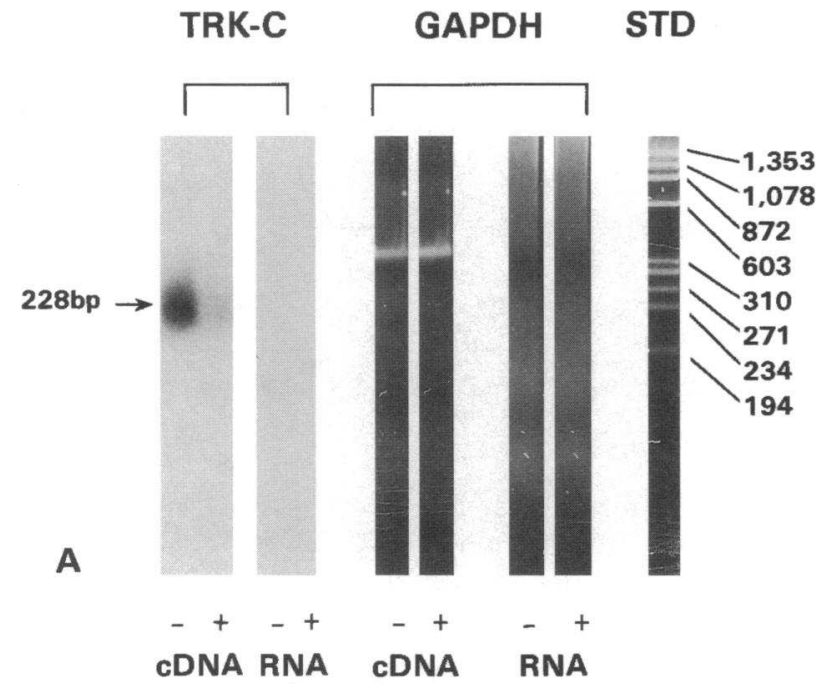

TRK
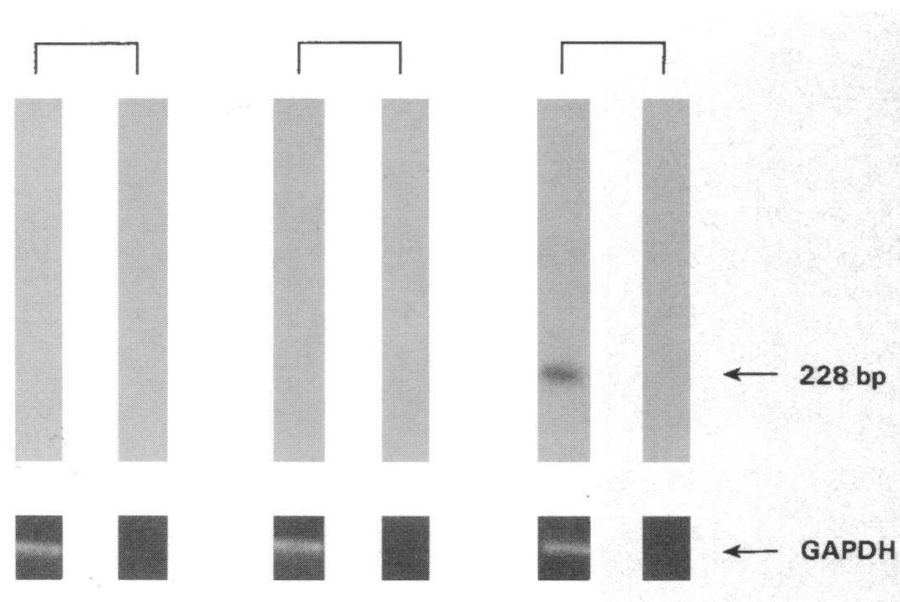

B

cDNA RNA

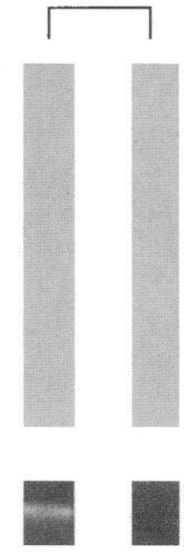

TRK-B

CDNA RNA
TRK-C

CDNA RNA
Figure 4. trk-C gene expression by human melanocytes. (A) Southern blot analysis of PCR products ( 40 cycles) of reverse-transcribed control $(-)$ and TPA-stimulated $(+)$ melanocyte cDNA, and non-reverse-transcribed melanocyte mRNA of the same samples separated on $1.5 \%$ agarose gel. The blot was hybridized to ${ }^{32} \mathrm{P}$-labeled porcine trk-C cDNA. A strong band is seen in control melanocyte cDNA and a fainter band is seen in TPAstimulated melanocyte cDNA. No band is seen in nonreverse-transcribed melanocyte mRNA, excluding the possibility that the trk-C band was generated from contaminating genomic DNA. Ethidium bromide-stained PCR products of reverse-transcribed control and TPAstimulated melanocyte mRNA, amplified using sequence-specific human GAPDH primers separated on 3\% agarose gel, suggest comparable amplification of both samples. Standard (STD) is $\phi \chi 174$ replicative form DNA digested with Hoe III. (B) Southern blot analysis of PCR products ( 20 cycles) of reverse-transcribed control melanocyte cDNA and non-reversetranscribed melanocyte mRNA of the same samples separated on $1.5 \%$ agarose gel. The blots were hybridized at the same time to equal amounts of comparable specific activity radiolabeled trk, trk-C, and trk-B cDNAs. A strong band is seen only in melanocyte cDNA hybridized with trk-C cDNA. No band is seen in non-reversetranscribed melanocyte mRNA. Ethidium bromidestained PCR products of reverse-transcribed melanocyte mRNA, amplified with GAPDH primers separated on $3 \%$ agarose gel, display bands of comparable intensity in all samples. two cDNAs produced by the $3^{\prime}$ RACE procedure (Fig. $10 \mathrm{~A}$ ) represent two distinct polyadenylated mRNAs. However, the possibility of two different splicing patterns of the mRNA cannot be excluded.

\section{Discussion}

Our experiments demonstrate that human melanocytes express high affinity tyrosine kinase receptors for both NGF and NT3 , and that trk becomes phosphorylated in melanocytes within minutes after their stimulation with NGF. We also show that cultured human fibroblasts strongly express NT-3 mRNA, that this expression is modulated by presumptively physiologic signals, and that NT-3 supplementation enhances melanocyte survival when maintained in medium-lacking growth factors. Taken together with previous work showing that melanocytes express p75 NGF receptor and respond to NGF stimulation (3, 4 ), and that keratinocytes express NGF, this work strongly suggests that melanocytes utilize the same neurotrophin signalling molecules as do central nervous system (CNS) neurons.

Our work documents both trk and trk-C mRNA expression in human melanocytes, and it shows that outside signals such as TPA modulate their expression. We have demonstrated previously that after TPA stimulation, the p75 NGF receptor is

Figure 3. Indirect immunofluorescent analysis of trk protein expression in melanocytes grown on Labtek slides. Representative melanocytes are shown $(A, C$, and $E)$. The amount of fluorescence of the representative cell was quantified using a confocal microscope $(B, D$, and $F)$. Purified rabbit anti-trk IgG strongly bound to TPA-stimulated melanocytes $(A$ and $B)$ and to melanocytes in TPA-stimulated keratinocyte/melanocyte cocultures $(C$ and $D)$. Keratinocytes in keratinocyte/melanocyte cocultures analyzed at the same laser voltage and intensity were negative ( $E$ and $F)$. In all different conditions, melanocytes incubated with normal rabbit IgG as an additional control were negative. Histograms $(B, D$, and $F)$ were generated by computer. (The analyzed field consists of 6,000 squares [pixels] and the computer assigns to each a fluorescent intensity of $0-$ 300 [ $x$ axis]. The $y$ axis depicts the number of pixels of each intensity.) 

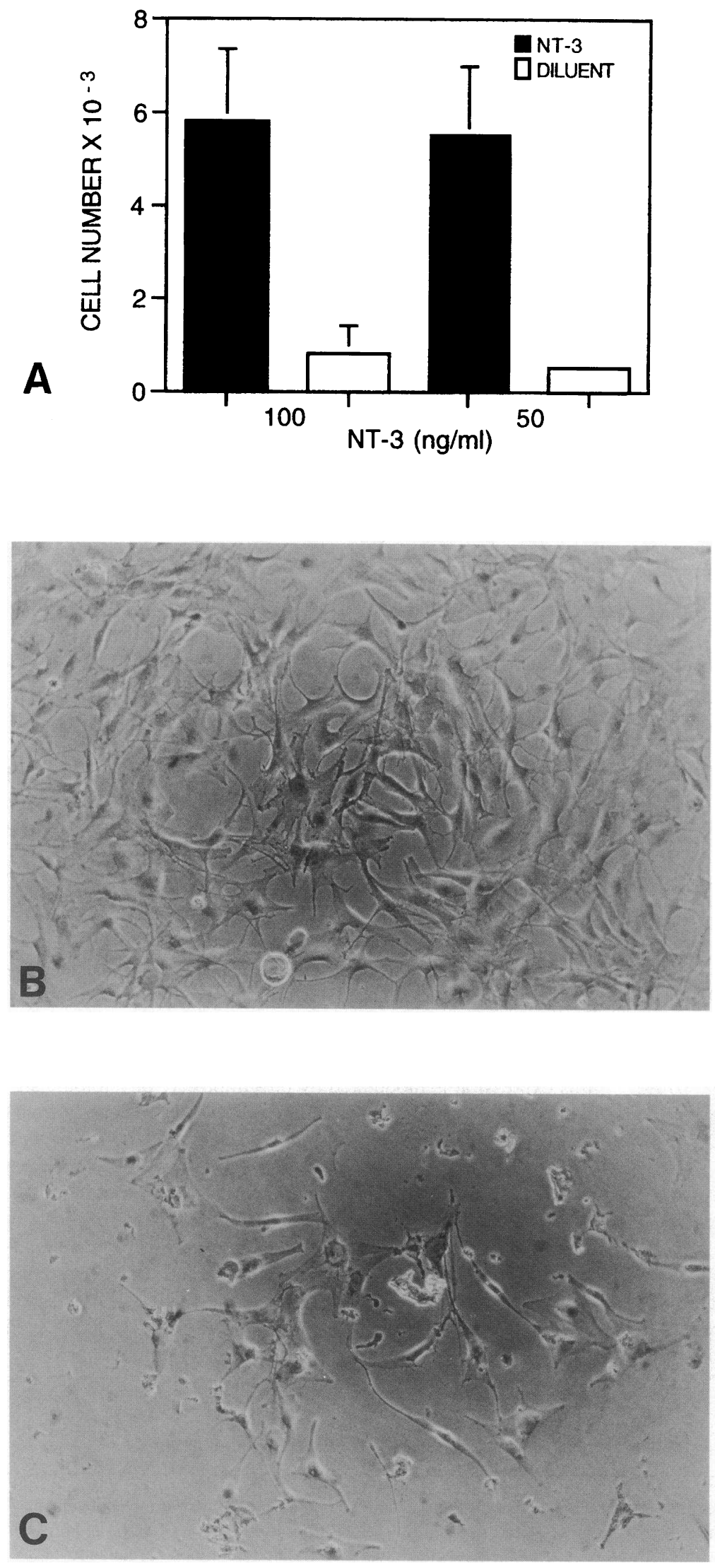

Figure 5. NT-3 effect on melanocyte survival. (A) Confluent melanocyte cultures were maintained for $3 \mathrm{~d}$ in Medium 199 alone and then were stimulated with 50 or $100 \mathrm{ng} / \mathrm{ml}$ recombinant human NT-3 ( $\boldsymbol{\square})$, or diluent alone $(\square)$ ( 7 ). Cell yields determined $72 \mathrm{~h}$ after NT-3 addition show $>10$-fold increase in melanocyte yield in cultures supplemented with NT-3. One representative experiment in triplicate (mean $\pm \mathrm{SD}$ ) is shown. $(B)$ Phase contrast micrograph of melanocytes maintained in $\mathrm{Me}$ dium 199 supplemented with $50 \mathrm{ng} / \mathrm{ml}$ NT-3. Confluent melanocytes appear healthy and spread on the dish surface. $(C)$ Phase contrast micrograph of melanocytes maintained in Medium 199 supplemented with diluent alone. Melanocytes are dying and detaching from the dish surface. 


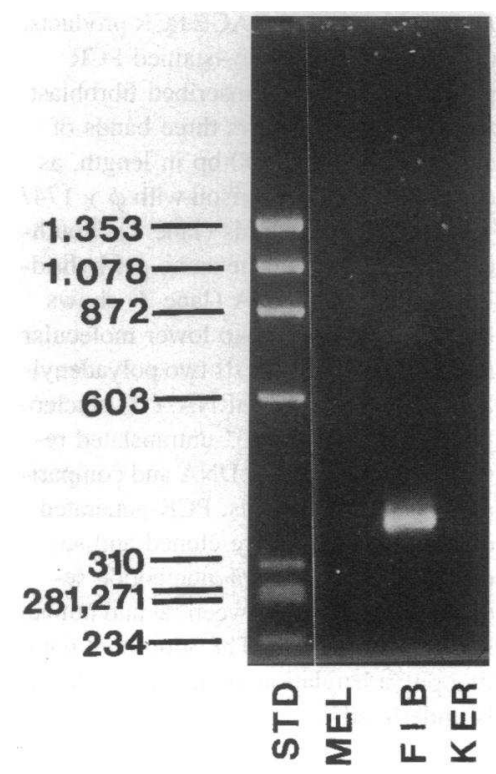

Figure 6. NT-3 PCR product. Ethidium bromide-stained PCR product of reverse-transcribed melanocyte $(M E L)$, fibroblast $(F I B)$, and keratinocyte $(K E R)$ mRNAs using primers complementary to rat NT-3 sequences. A strong band of the predicted 357-bp size is seen after 40 cycles only in the lane containing fibroblast cDNA.

upregulated in melanocytes (3). There are reports suggesting that p75 NGF receptor is necessary for high affinity binding of NGF in cells that express low levels of trk, as the mutant pheochromocytoma cell line NR18 (19). Our experiments suggest that melanocytes express low trk levels. It is therefore reasonable that TPA, which upregulates p75 NGF receptor in melanocytes, also upregulates trk to facilitate NGF binding.

The mechanism of TPA-induced upregulation of p75 NGF receptor and trk expression in melanocytes is not known. TPA has a striking effect on melanocyte dendricity, resulting in a neuron-like morphology. It is possible that this differentiated morphology of melanocytes is part of an integrated complex of differentiated functions that includes induction of receptors to NGF. Because TPA acts through PKC, it is possible that PKC activation in melanocytes is necessary for dendrite formation,

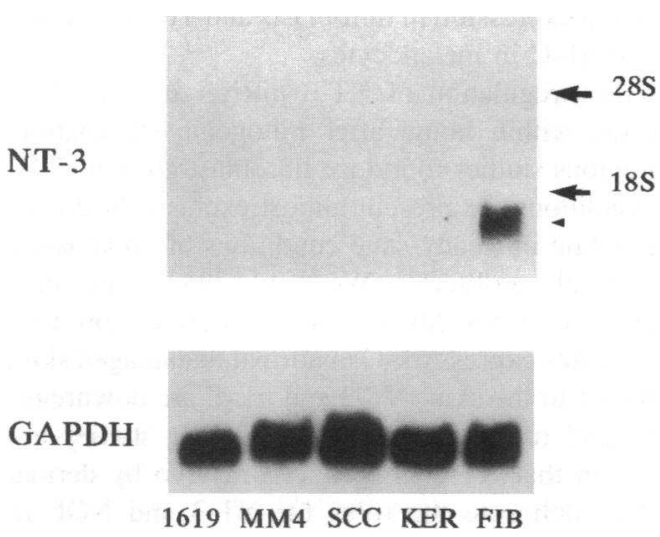

Figure 7. NT-3 gene expression by human fibroblasts. $10 \mu \mathrm{g}$ of total cellular RNA harvested from two human melanomas (1619 and MM4), squamous cell carcinoma (SCC), keratinocytes (KER), and fibroblasts (FIB) was hybridized with ${ }^{32} \mathrm{P}$-labeled PCR product of NT-3 cDNA in the Northern blot analysis. Only RNA from fibroblast sample hybridized with the probe demonstrating 1.4-kb transcripts. Hybridization of the blot with a cDNA probe for GAPDH as a constitutively expressed internal control demonstrates comparable loading of the RNA samples.
NT-3

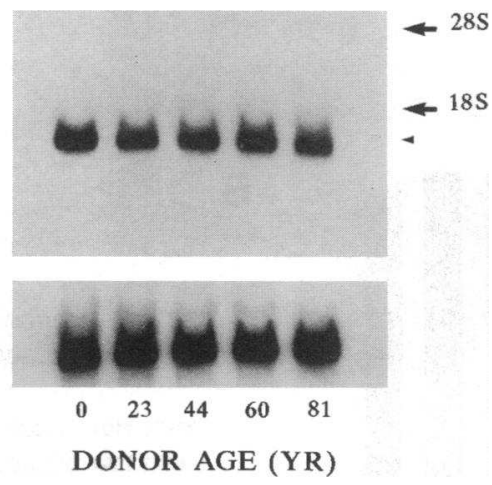

Figure 8. NT-3 gene expression by human fibroblasts from donors of different ages. $10 \mu \mathrm{g}$ of total cellular RNA was harvested from fibroblasts derived from 23-81-yr-old donors and was hybridized with ${ }^{32}$ P-labeled PCR product of NT-3 cDNA in the Northern blot analysis. NT-3 1.4-kb transcripts are strongly expressed by fibroblasts from all donors. Hybridization of the blot with a cDNA probe for GAPDH as a constitutively expressed internal control demonstrates comparable loading of the RNA samples.

as well as for trk and p75 NGF receptor induction. Further experiments are required to delineate this point.

In contrast with trk expression, melanocytes express trk-C primarily under baseline conditions and trk- $\mathrm{C}$ is downregulated after TPA. These findings suggest that melanocytes can bind both NGF and NT-3, but different signals will induce one receptor or the other. Thus, the extent of NGF and NT-3 binding in melanocytes may be influenced by outside signals through modulation of their high affinity receptor expression.
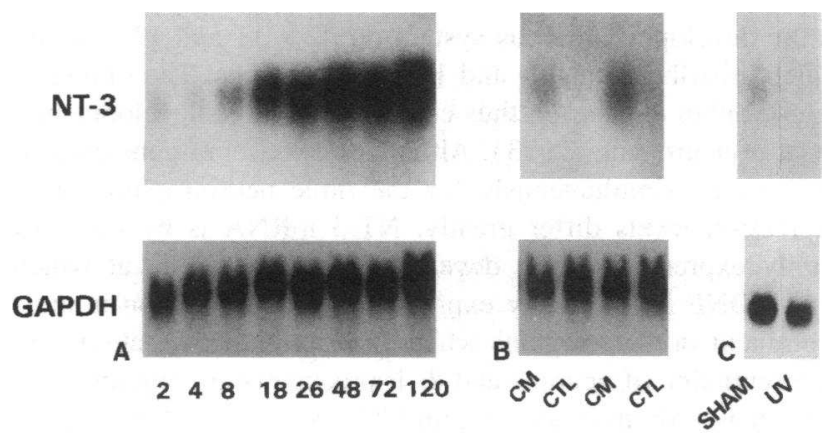

Hours After

Melanocyte

Medium

Figure 9. Modulation of NT-3 gene expression in fibroblasts. (A) 20 $\mu \mathrm{g}$ of total cellular RNA was harvested from fibroblasts at the indicated times $(2,4,8,18,26,48, j 2$, and $120 \mathrm{~h})$ after supplementation of fresh medium. NT-3 1.4-kb transcript intensity gradually increases 25 -fold through $5 \mathrm{~d}$. (B) $20 \mu \mathrm{g}$ of total cellular RNA was harvested from fibroblasts maintained for $6 \mathrm{~h}$ in melanocyte-conditioned medium ( $C M$, two different melanocyte donors), or in the same medium not conditioned by melanocytes ( $C T L$ ). NT-3 1.4-kb transcripts were observed only in samples maintained in medium conditioned by melanocytes. No NT-3 mRNA transcripts are observed in fibroblasts maintained in fresh nonconditioned medium. (C) $20 \mu \mathrm{g}$ of total cellular RNA was harvested from fibroblasts $6 \mathrm{~h}$ after $32 \mathrm{~mJ} \cdot \mathrm{cm}^{-2} \mathrm{UV}-\mathrm{B}$ irradiation ( $U V$ ) or sham irradiation (SHAM). In both conditions, after irradiation, fibroblasts received their old medium back. UV irradiation of fibroblasts downregulated their NT-3 mRNA level more than 11-fold. 


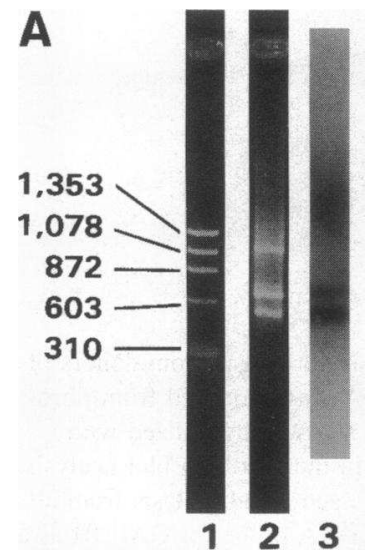

B

hNT-3 1029 TTTT CTCAATAAAAT CAGTGTGCTTGCCTTCCCT INT-3 1008 TTTTTTCTCAATAAAATTC GTGTGCTTGCCTTCGCT

hNT-3 1064 CAGGCCTCTCCCATCTGTTAAAACTTGTTTTGTGAT INT-3 1045 CAGGCCTCTCCCATCTGTT AACCTTGTTTTGTGAT

hNT-3 1101 CCGGGTCTCAGGAGTCACTCTGTAAAATCTGTGTACG rNT-3 1081 TGGGCTCTC GGGAACCTTCTGTAAAACCTGTGTACA

hNT-3 1139 CCAGTATTTTGCATTCAGTATTGTCAAGGCCAT NT-3 1118 CCAGTATTTGGCATTCAGTATTGTCAA

hNT-3 1173 GACTGTTGTTTTAGTAAACTAGTTAAAAT
Figure 10. NT-3 3' RACE PCR products. (A) Ethidium bromide-stained PCR product of reverse-transcribed fibroblast mRNA (lane 2) shows three bands of $\sim 1,080,630$, and $500 \mathrm{bp}$ in length, as determined by comparison with $\phi \chi 174 /$ HoeIII digest standards (lane 1 ). Southern blot analysis of the same gel hybridized with NT-3 cDNA (lane 3) shows binding only to the two lower molecular mass bands and suggests two polyadenylation sites for NT-3 mRNA. (B) Nucleotide sequence of the $3^{\prime}$ untranslated region of human NT-3 cDNA and comparison with rat sequences. PCR-generated cDNA fragments were cloned and sequenced. There is $86 \%$ nucleotide sequence homology between rat and human NT-3 in this region. The additional putative polyadenylation signal AATAAAA is underlined.
Neurotrophin effects on embryonic and adult animal neurons have been extensively studied in culture. Cell degeneration is found to occur in these systems when neurons are maintained in culture in the absence of neurotrophins $(8,9,14,15,67-$ $69,71)$. NT-3 has been shown in vitro to support the survival of developing chick sympathetic, sensory, and dorsal root ganglia neurons $(14,15,72)$, as well as quail neural crest neurons $(71)$. We observe the same effect of NT-3 on melanocytes maintained in medium lacking growth factors. Under these conditions NT3 prevents melanocyte death.

Studies checking expression of the various neurotrophic factors during embryogenesis in rats (73) found that all neurotrophic factors (NGF, NT-3, and BDNF) begin to be expressed in the developing nervous system on days 11 and 12 , and are widely distributed in 12- and 13-d-old embryos. The timing of neurotrophin expression thus coincides with the developmental onset of neurogenesis (73). Although the onset of gene expression occurs simultaneously for the three neurotrophins, their expression levels differ greatly. NT-3 mRNA is by far most highly expressed during development of the CNS, at which time BDNF is minimally expressed. NT-3 expression is most prominent in CNS regions where proliferation, migration, and differentiation of neurons and their precursors are ongoing, and it decreases dramatically within CNS regions as they mature. Conversely, BDNF expression becomes most prominent in CNS regions as they mature, suggesting that NT -3 and BDNF may act at different times during embryogenesis on the same neuronal population (73). Within the adult human, CNS, NT-3, and BDNF have similar distributions, and they are expressed mainly in the cerebellum, hippocampus, basal ganglia, and nuc basalis $(13,66)$. However, they have dramatically different patterns of expression within the adult human peripheral tissues. NT-3 is expressed in all tissues surveyed: heart, lung, kidney, liver, eye, and placenta. In contrast, BDNF transcripts are detected only in the heart and lung, suggesting a wider range of activities for NT-3 $(13,66)$.

To examine NT-3 expression and modulation in fibroblasts, we used NT-3 cDNA cloned from human fibroblasts as a probe. We found a high level of expression of NT-3 mRNA in fibroblasts of newborns as well as adult donors of different ages, suggesting a possible role for NT-3 in postnatal and adult skin, presumably involving melanocytes that express receptors to NT-3.

Modulations in NT-3 expression were reported in adult rat brain after injury that resulted in ischemic and hypoglycemic coma (66). While NGF and BDNF mRNAs are markedly increased after these insults, NT-3 mRNA is reduced. We found significant downregulation of NT-3 mRNA in fibroblasts after UV irradiation, in contrast to the previously reported upregulation of NGF mRNA and bioactivity in UV-irradiated keratinocytes (5). UV is known to affect membrane phospholipid constituents whose derivatives may act as second messengers through the activation of phospholipase $\mathrm{C}$, which releases diacylglycerol from the membrane. Diacylglycerol, in turn, activates PKC (74). Like diacylglycerol, TPA activates $\operatorname{PKC}(75,76)$. Thus, TPA stimulation of melanocytes may mimic some UVmediated effects on cells. It is interesting, therefore, that UV increases NGF expression in keratinocytes and that TPA increases the expression of both p75 NGF receptor (3) and trk, the high affinity NGF receptor, in melanocytes. Concomitantly, UV decreases NT-3 expression in fibroblasts and TPA decreases the expression of trk-C in melanocytes.

Significant downregulation of NT-3 mRNA in fibroblasts was also detected within hours after mitogenic stimulation, known from previous studies to induce fibroblast growth (77). In vivo, such conditions are present almost exclusively during wound healing, while in steady-state conditions of undamaged skin, fibroblasts rarely proliferate. We would like to speculate that, in analogy to the CNS, fibroblasts constitutively produce NT-3 and melanocytes express trk-C in normal undamaged skin, while, after damage to the skin, NT-3 and trk-C are downregulated and NGF and trk are upregulated. Further studies are required to confirm that NT-3 is produced in vivo by dermal fibroblasts and to delineate the roles for NT-3 and NGF in normal, injured, and diseased human skin.

Melanocytes supplemented with NT-3 appear more dendritic than control melanocytes maintained in Medium 199 alone. It is, however, difficult to compare melanocyte morphology under these conditions because control cells are at various stages of degeneration. Addition of NT-3 to melanocytes cultured in the presence of serum had only subtle effect on their dendricity (data not shown). It is possible that NT-3 primarily 
mediates melanocyte survival rather than dendrite formation, or that certain components required to promote melanocyte dendricity in the presence of NT-3 were not present in our experiment.

In vivo, melanocytes display dendrites in the presence of surrounding keratinocytes. However, melanocytes in vitro do not display dendritic morphology unless they are stimulated with TPA or are cocultured with keratinocytes. To investigate possible paracrine effects of keratinocytes on melanocytes, we used keratinocyte/melanocyte cocultures. Our work suggests that keratinocyte-derived paracrine signals potentiate the TPA induction of trk expression in melanocytes. Under coculture conditions, trk expression in melanocytes is stronger than in TPA-stimulated pure melanocyte cultures. This is particularly interesting, given that keratinocytes are the predominant source for NGF in the epidermis $(5,6)$ and might, therefore, logically also produce factors that modulate the expression of its high affinity receptor.

Within 5 min of NGF stimulation, melanocytes demonstrated tyrosine phosphorylation of a broad band at a molecular mass of $\sim 130-140 \mathrm{kD}$, suggesting trk phosphorylation. An additional protein phosphorylated on tyrosine with a mol mass of $\sim 110 \mathrm{kD}$ was observed as well. Moreover, two bands of $\sim 130 \mathrm{kD}$ and $110 \mathrm{kD}$ were also detected with anti-trk antibodies. The primary translational product of trk gene is a $110-\mathrm{kD}$ GP that becomes further glycosylated, presumably during its transport to the plasma membrane, to yield a $140-\mathrm{kD}$ GP (58). Both the 110 - and $140-\mathrm{kD}$ proteins exhibit in vitro tyrosine kinase activity. Therefore, one possibility is that in melanocytes, both forms of trk represent the mature receptor and become phosphorylated upon stimulation with NGF. However, at least in NIH 3T3 cells, only the $140-\mathrm{kD}$ isoform is localized on the cell surface, suggesting that only the $140-\mathrm{kD}$ form is the mature receptor (58). Another possibility, although unlikely, is that between the time of protein extraction and boiling of the samples, the $110-\mathrm{kD}$ trk became phosphorylated in vitro.

Still another possibility is that the $110-\mathrm{kD}$ band represents a component of the intracellular signal transduction induced by trk phosphorylation. trk activation leads to increase in phosphotyrosine of several proteins including extracellular signal-regulated kinases $(51,52)$ and phospholipase $C(78)$. The molecular masses of these specific proteins are not $\sim 110 \mathrm{kD}$, but other as yet unidentified second messengers could be phosphorylated on tyrosine after trk phosphorylation.

To our knowledge, the present study is the first attempt to show expression and modulation of the high afinity receptors to NGF and NT-3 in human nearal crest-derived cells. Our results are consistent with a possible role for NTs in modulation of melanocyte function in skin.

\section{Acknowledgment}

This work was supported in part by National Institutes of Health grant HD-24538.

\section{References}

1. Boissy, R. E. 1988. The melanocyte: its structure, function, and subpopulations in skin, eyes, and hair. In Pigmentations Disorders Dermatologic Clinics. vol. 6. J. J. Nordlund, editor. W. B. Saunders Co., Philadelphia. pp. 161-173.

2. Yaar, M., and B. A. Gilchrest. 1991. Human melanocyte growth and differentiation: A decade of new data. J. Invest. Dermatol. 97:611-617.

3. Peacocke, M., M. Yaar, C. P. Mansur, M. V. Chao, and B. A. Gilchrest.
1988. Induction of nerve growth factor receptors on cultured human melanocytes. Proc. Natl. Acad. Sci. USA. 85:5282-5286.

4. Yaar, M., K. Grossman, M. Eller, and B. A. Gilchrest. 1991. Evidence for nerve growth factor-mediated paracrine effects in human epidermis. J. Cell Biol. 115:821-828.

5. Tron, V. A., M. D. Coughlin, D. E. Jang, J. Stanisz, and D. N. Sauder. 1990. Expression and modulation of nerve growth factor in murine keratinocytes (PAM 212). J. Clin. Invest. 85:1085-1089.

6. Di-Marco, E., P. C. Marchisio, S. Bondanza, A. T. Franzi, R. Cancedda, and M. De Luca. 1991. Growth regulated synthesis and secretion of biologically active nerve growth factor by human keratinocytes. J. Biol. Chem. 32:2171821722.

7. Bothwell, M. 1991. Keeping track of neurotrophin receptors. Cell. 65:915918.

8. Levi-Montalcini, R. 1987. The nerve growth factor: thirty-five years later. EMBO (Eur. Mol. Biol. Organ.) J. 6:1145-1154.

9. Barde, Y. A., D. Edgar, and H. Thoenen. 1982. Purification of a new neurotrophic factor from mammalian brain. EMBO (Eur. Mol. Biol. Organ.) J. 1:549-553.

10. Leibrock, J., F. Lottspeich, A. Hohn, M. Hofer, B. Hengerer, P. Masiakowski, H. Thoenen, and Y. A. Barde. 1989. Molecular cloning and expression of brain-derived neurotrophic factor. Nature (Lond.). 341:149-152.

11. Ernfors, P., C. Wetmore, L. Olson, and H. Persson. 1990. Identification of cells in rat brain and peripheral tissues expressing mRNA for members of the nerve growth factor family. Neuron. 5:511-526.

12. Hohn, A., J. Leibrock, K. Bailey, and Y. A. Barde. 1990. Identification and characterization of a novel member of the nerve growth factor/brain-derived neurotrophic factor family. Nature (Lond.). 344:339-341.

13. Jones, K. R., and L. F. Reichardt. 1990. Molecular cloning of a human gene that is a member of the nerve growth factor family. Proc. Natl. Acad. Sci. USA. 87:8060-8064.

14. Maisonpierre, P. C., L. Belluscio, S. Squinto, N. Y. Ip, M. E. Furth, R. M. Lindsay, and G. D. Yancopoulos. 1990. Neurotrophin-3: a neurotrophic factor related to NGF and BDNF. Science (Wash. DC). 247:1446-1451.

15. Rosenthal, A., D. V. Goeddel, T. Nguyen, M. Lewis, A. Shih, G. R. Laramee, K. Nikolics, and J. W. Winslow. 1990. Primary structure and biological activity of a novel human neurotrophic factor. Neuron. 4:767-773.

16. Hallbook, F., C. F. Ibanez, and H. Persson. 1991. Evolutionary studies of the nerve growth factor family reveal a novel member abundantly expressed in Xenopus ovary. Neuron. 6:845-858.

17. Snyder, S. H. 1991. Fresh factors to consider. Nature (Lond.). 350:195.

18. Chao, M. V., M. A. Bothwell, A. H. Ross, H. Koprowski, A. A. Lanahan, C. R. Buck, and A. Sehgal. 1986. Gene transfer and molecular cloning of the human NGF receptor. Science (Wash. DC). 232:518-521.

19. Hempstead, B. L., D. Martin-Zanca, D. R. Kaplan, L. F. Parada, and M. V. Chao. 1991. High-affinity NGF binding requires co-expression of the trk proto-oncogene and low-affinity NGF receptor. Nature (Lond.). 350:678-683.

20. Rodriguez-Tebar, A., G. Dechant, and Y. A. Barde. 1990. Binding of brain-derived neurotrophic factor to the nerve growth factor receptor. Neuron. 4:487-492.

21. Squinto, S. P., T. N. Stitt, T. H. Aldrich, S. Davis, S. M. Bianco, C. Radziejewski, D. J. Glass, P. Masiakowski, M. E. Furth, D. M. Valenzuela et al. 1991. trkB encodes a functional receptor for brain-derived neurotrophic factor and neurotrophin-3 but not nerve growth factor. Cell. 61:203-212.

22. Cordon-Cardo, C., P. Tapley, S. Jing, V. Nanduri, E. O'Rourke, F. Lamballe, K. Kovary, R. Klein, K. R. Jones, L. F. Reichardt et al. 1991. The trk tyrosine protein kinase mediates the mitogenic properties of nerve growth factor and neurotrophin-3. Cell. 66:173-183.

23. Klein, R., V. Nanduri, S. Jing, F. Lamballe, P. Tapley, S. Bryant, C. Cordon-Cardo, K. R. Jones, L. F. Reichardt, and M. Barbacid. 1991. The trkB tyrosine protein kinase is a receptor for brain-derived neurotrophic factor and neurotrophin-3. Cell. 66:395-403.

24. Kaplan, D. R., D. Martin-Zanca, and L. F. Parada. 1991. Tyrosine phosphorylation and tyrosine kinase activity of the trk proto-oncogene product induced by NGF. Nature (Lond.). 350:158-160.

25. Kaplan, D. R., B. L. Hempstead, D. Martin-Zanca, M. V. Chao, and L. F. Parada. 1991. The trk proto-oncogene product: a signal transducing receptor for nerve growth factor. Science (Wash. DC). 252:554-557.

26. Soppet, D., E. Escandon, J. Maragos, D. S. Middlemas, S. W. Reid, J. Blair, L. E. Burton, B. R. Stanton, D. R. Kaplan, T. Hunter et al. 1991. The neurotrophic factors brain-derived neurotrophic factor and neurotrophin-3 are ligands for the trkB tyrosine kinase receptor. Cell. 65:895-903.

27. Lamballe, F., R. Klein, and M. Barbacid. 1991. Trk C a new member of tyrosine protein kinases is a receptor for neurotrophin-3. Cell. 66:967-979.

28. Martin-Zanca, D., M. Barbacid, and L. F. Parada. 1990. Expression of the trk proto-oncogene is restricted to the sensory cranial and spinal ganglia of neural crest origin in mouse development. Genes \& Dev. 4:638-694.

29. Klein, R., L. F. Parada, F. Coulier, and M. Barbacid. 1989. TrkB, a novel tyrosine protein kinase receptor expressed during mouse neural development. EMBO (Eur. Mol. Biol. Organ.) J. 8:3701-3709. 
30. Klein, R., D. Martin-Zanca, M. Barbacid, and L. F. Parada. 1990. Expression of the tyrosine kinase receptor gene trkB is confined to the murine embryonic and adult nervous system. Development (Camb.). 109:845-850.

31. Klein, R., D. Conway, L. F. Parada, and M. Barbacid. 1990. The trkB tyrosine protein kinase gene codes for a second neurogenic receptor that lacks the catalytic kinase domain. Cell. 61:647-656.

32. Middlemas, D. S., R. A. Lindberg, and T. Hunter. 1991. Trk B, a neura receptor protein-tyrosine kinase: evidence for a full length and two truncated receptors. Mol. Cell. Biol. 11:143-153.

33. Castagna, M., Y. Takai, K. Kaibuchi, K. Sano, U. Kikkawa, and Y. Nishizuka. 1982. Direct activation of calcium-activated, phospholipid-dependent protein kinase by tumor-promoting phorbol esters. J. Biol. Chem. 257:78487851

34. Niedel, J. E., L. J. Kuhn, and G. R. Vandenbark. 1983. Phorbol diester receptor copurifies with protein kinase C. Proc. Natl. Acad. Sci. USA. 80:36-40.

35. Rozengurt, E., A. Rodriquez-Pena, and K. A. Smith. 1983. Phorbol esters, phospholipase $\mathrm{C}$, growth factors rapidly stimulate the phosphorylation of a $\mathbf{M}_{r}$ 80,000 protein in intact quiescent 3T3 cells. Proc. Natl. Acad. Sci. USA. 80:72447248.

36. Hunter, T., N. Ling, and J. A. Cooper. 1984. Protein kinase C phosphorylation of the EGF receptor at a threonine residue close to the cytoplasmic residue close to the cytoplasmic face of the plasma membrane. Nature (Lond.) 311:480483.

37. Bollag, G. E., R. A. Roth, J. Beaudoin, D. Mochly-Rosen, and D. E. Koshland. 1986. Protein kinase C directly phosphorylates the insulin receptor in vitro and reduces its protein-tyrosine kinase activity. Proc. Natl. Acad. Sci. USA 83:5822-5824.

38. Jeng, A. Y., S. K. Srivastava, J. C. Lacal, and P. Blumberg. 1987. Phosphorylation of ras oncogene product by protein kinase C. Biochem. Biophys. Res. Commun. 145:782-788.

39. Blackshear, P. J. 1993. The MARCKS family of cellular protein kinase C substrates. J. Biol. Chem. 268:1501-1504.

40. Whitfield, J. F., J. P. Durkin, D. J. Franks, L. P. Kleine, L. Raptis, R. H Rixon, M. Sikorska, and P. R. Walker. 1987. Calcium, cyclic AMP and protein kinase C-partners in mitogenesis. Cancer Metastasis Rev. 5:205-250.

41. Fisch, T. M., R. Prywes, and R. G. Roeder. 1987. c-fos sequences necessary for basal expression and induction by epidermal growth factor, 12-0-tetradecanoy phorbol-13-actate, and the calcium ionophore. Mol. Cell Biol. 7:3490-3502.

42. Kelly, K., B. H. Cochran, C. D. Stiles, and P. Leder. 1984. Cell-specific regulation of the c-myc gene by lymphocyte mitogenes and platelet-derived growth factors. Cell. 35:603-610.

43. Greenberg, M. E., and E. B. Ziff. 1984. Stimulation of 3T3 cells induces transcription of the c-fos proto-oncogene. Nature (Lond.). 311:433-438.

44. Ciesielski-Treska, J., G. Ulrich, and D. J. Aunis. 1991. Protein kinase Cinduced redistribution of the cytoskeleton and phosphorylation of vimentin in cultured brain macrophages. J. Neurosci. Res. 29:362-378.

45. Kiley, S. C., P. J. Parker, D. Fabbio, and S. Jaken. 1992. Hormone- and phorbol ester-activated protein kinase $\mathrm{C}$ isozymes mediate a reorganization of the actin cytoskeleton associated with prolactin secretion in $\mathrm{GH}_{4} \mathrm{C}_{1}$ cells. Endocrinology. 6:120-131.

46. Sihag, R. K., A. Y. Jeng, and R. A. Nixon. 1988. Phosphorylation of neurofilament proteins by protein kinase C. FASEB (Fed. Am. Soc. Exp. Biol.) J. 233:181-185

47. Eisinger, M., and O. Marko. 1982. Selective proliferation of normal human melanocytes in vitro in the presence of phorbol ester and cholera toxin. Proc. Natl. Acad. Sci. USA. 79:2018-2022.

48. Gilchrest, B. A. 1980. Prior sun exposure decreases the lifespan of human skin fibroblasts in vitro. J. Gerontol. 35:537-541.

49. Gilchrest, B. A. 1979. Relationship between actinic damage and chronologic aging in keratinocyte cultures of human skin. J. Invest. Dermatol. 72:219 223

50. Gilchrest, B. A., M. A. Vrabel, E. Flynn, and G. Szabo. 1984. Selective cultivation of human melanocytes from newborn and adult epidermis. J. Invest. Dermatol. 83:370-376.

51. Sozeri, O., K. Vollmer, M. Liyanage, D. Frith, G. Kour, G. E. Mark 3rd, S. Stabel, and G. E. Mark. 1992. Activation of the c-Raf protein kinase by protein kinase C phosphorylation. Oncogene. 7:2259-2262.

52. Kolch, W., G. Heldecker, G. Kochs, R. Hummel, H. Vahldl, H. Mischak, G. Finkenzeller, D. Marmé, and U. R. Rapp. 1993. Protein kinase C $\alpha$ activates RAF-1 by direct phosphorylation. Nature (Lond.). 364:249-252.

53. Rheinwald, J. G., E. Germain, and M. A. Beckett. 1983. Expression of keratins and enveloped proteins in normal and malignant human keratinocytes and mesothelial cells. In Human Carcinogenesis. C. E. Harris and H. N. Autrup, editors. Academic Press, New York. pp. 85-96.

54. Naeyaert, J. M., M. Eller, P. R. Gordon, and B. A. Gilchrest. 1991. Pigmen content of cultured human melanocytes does not correlate with tyrosinase message level. Br. J. Dermatol. 125:297-303.

55. Werninghaus, K. I., and B. A. Gilchrest. 1991. Protective effect of alpha tocopherol in carrier liposomes on ultraviolet-mediated human epidermal cel damage in vitro. Photodermatol. Photoimmunol. \& Photomed. 8:236-242.

56. Friedmann, P. S., and B. A. Gilchrest. 1987. Ultraviolet radiation directly induces pigment production by cultured human melanocytes. J. Cell. Physiol. 133:88-94.

57. Maniatis, T., E. F. Fritsch, and J. Sambrook. 1982. Molecular Cloning: A Laboratory Manual. Cold Spring Harbor Laboratory, Cold Spring Harbor, NY $545 \mathrm{pp}$.

58. Martin-Zanca, D., R. Oskam, G. Mitra, T. Copeland, and M. Barbacid 1989. Molecular and biochemical characterization of the human trk proto-oncogene. Mol. Cell. Biol. 9:24-33.

58a. Martin-Zanca, D., S. H. Hughes, and M. Barbacid. 1986. A human oncogene formed by the fusion of truncated tropomyosin and protein tyrosine kinase sequences. Nature (Lond.). 319:743-748.

59. Tso, J. Y., X. H. Sun, T. Kao, K. S. Reece, and R. Wu. 1985. Isolation and characterization of rat and human glyceraldehyde- 3 phosphate dehydrogenase cDNAs: genomic complexity and molecular evolution of the gene. Nucleic Acids Res. 13:2485-2502.

60. Dean, M., R. Kent, and G. Sonenshein. 1983. Transcriptional activation of immunoglobulin a heavy-chain genes by translocation of the c-myc oncogene. Nature (Lond.). 305:443-446.

61. Kawasaki, E. 1990. Amplification of RNA sequences via complementary DNA (cDNA). In PCR Protocols: A Guide to Methods and Applications. M Innis, D. Gelfand, J. Sninsky, and T. White, editors. Academic Press, San Diego, CA. pp. 21-27.

62. Frohman, M. 1990. RACE: Rapid amplification of cDNA ends. In PCR Protocols: A Guide to Methods and Applications. M. Innis, D. Gelfand, J. Sninsky, and T. White, editors. Academic Press, San Diego, CA. pp. 28-38.

63. Sanger, F., S. Nicklen, and A. R. Coulson. 1977. DNA sequencing with chain terminating inhibitors. Proc. Natl. Acad. Sci. USA. 74:5463-5467.

64. Svoboda, K. K. H. 1991. Intracellular localization of types I and II collagen mRNA and endoplasmic reticulum in embryonic corneal epithelia. J. Cell Sci. 100:23-33

65. Svoboda, K. K. H. 1992. Embryonic corneal epithelial actin alters distribution in response to laminin. Invest. Ophthalmol. 33:324-333.

66. Maisonpierre, P. C., M. M. Le Beau, R. Espinosa, N. Y. Ip, L. Belluscio, S. M. de la Monte, S. Squinto, M. E. Furth, and G. D. Yancopoulos. 1991. Human and rat brain-derived neurotrophic factor and neurotrophin-3: gene structures, distributions, and chromosomal localizations. Genomics. 10:558-568.

67. Whittemore, S. R., and A. Seiger. 1987. The expression, localization, and functional significance of B-nerve growth factor in the CNS. Brain Res. 434:439464.

68. Thoenen, H., C. Bandtlow, and R. Heuman. 1987. The physiological function of nerve growth factor in the CNS: comparison with the periphery. Rev Physiol. Biochem. Pharmacol. 109:145-178.

69. Ebendal, T. 1990. NGF in CNS: experimental data and clinical implications. Prog. Growth Factor Res. 1:143-159.

70. Lindvall, O., P. Emfors, J. Bengzom, Z. Kokaia, M. L. Smith, B. K Siesjo, and H. Persson. 1992. Differential regulation of mRNAs for nerve growth factor, brain-derived neurotrophic factor, and neurotrophin 3 in the adult rat brain following cerebral ischemia and hypoglycemic coma. Proc. Natl. Acad. Sci. USA 89:648-652.

71. Kalcheim, C., C. Carmeli, and A. Rosenthal. 1992. Neurotrophin-3 is mitogen for cultured neural crest cells. Proc. Natl. Acad. Sci. USA. 89:16611665 .

72. Hory-Lee, F., M. Russell, R. M. Lindsay, and E. Frank. 1993. Neurotrophin 3 supports the survival of developing muscle sensory neurons in culture. Proc. Natl. Acad. Sci. USA. 90:2613-2617.

73. Maisonpierre, P. C., L. Belluscio, B. Friedman, R. F. Adlerson, S. J. Wiegand, M. E. Furth, R. M. Lindsay, and G. D. Yancopoulos. 1990. NT-3, BDNF, and NGF in the developing rat nervous system: parallel as well as reciprocal patterns of expression. Neuron. 5:501-509.

74. Nishizuka, Y. 1986. Studies and perspectives of protein kinase C. Science (Wash. DC). 233:305-312.

75. Bell, R. M. 1986. Protein kinase C activation by diacylglycerol second messengers. Cell. 45:631-632.

76. Nishizuka, Y. 1984. Turnover of inositol phospholipids and signal transduction. Science (Wash. DC). 225:1365-1370.

77. Yaar, M., M. Peacocke, M. S. Cohen, and B. A. Gilchrest. 1990. Dissociation of proto-oncogene induction from growth response in normal human fibroblasts. J. Cell Physiol. 145:39-45.

78. Vetter, M., D. Martin-Zanca, L. F. Parada, J. M. Bishop, and D. R. Kaplan. 1991. Nerve growth factor rapidly stimulates tyrosine phosphorylation of phospholipase C- $\gamma 1$ by a kinase activity associated with the product of the trk protooncogene. Proc. Natl. Acad. Sci. USA. 88:5650-5654. 